Verita Sriratana

Chulalongkorn University

verita.s@chula.ac.th

Milada Polišenská

Anglo-American University in Prague

milada.polisenska@aauni.edu

\title{
Translating and Transcending Censors: Modernist Appropriation and Thematisation of Censorship in the Works of Virginia Woolf, Allen Ginsberg, Czesław Miłosz and Bohumil Hrabal*
}

Aвstract: Sriratana Verita, Polišenská Milada, Translating and Transcending Censors: Modernist Appropriation and Thematisation of Censorship in the Works of Virginia Woolf, Allen Ginsberg, Czestaw Miłosz and Bohumil Hrabal. "Poznańskie Studia Slawistyczne" 14. Poznań 2018. Publishing House of the Poznan Society for the Advancement of the Arts and Sciences, pp. 289-312. ISSN 2084-3011.

Censorship has often been regarded as the archenemy of artists, thinkers and writers. But has this always been the case? This research paper proposes that censorship is not a total evil or adversarial force which thwarts and hinders twentieth-century writers, particularly those who were part of the artistic, aesthetic, philosophical and intellectual movement known as Modernism. Though the word "censor" originally means a Roman official who, in the past, had a duty to monitor access to writing, the agents of censorship - particularly those in the modern times - are not in every case overt and easy to identify. Though Modernist writers openly condemn censorship, many of them nevertheless take on the role of censors who not only condone but also undergo self-censorship or censorship of others. In many cases in Modernist literature, readership and literary production, the binary opposition of victim and victimiser, as well as of censored and censor, is questioned and challenged. This research paper offers an analysis of the ways in which Virginia Woolf (1882-1941), Allen Ginsberg (1926-1997), Czesław Miłosz (1911-2004) and Bohumil Hrabal (1914-1997) lived and wrote by negotiating with many forms of censorship ranging from state censorship, social censorship, political censorship, moral censorship to self-censorship. It is a study of the ways in which these writers problematise and render ambiguity to the seemingly clear-cut and mutually exclusive division between the oppressive censor and the oppressed writer.

${ }^{*}$ This research paper has been funded by the Kanchanapisek Faculty Research Grant, Kanchanapisek Chalermprakiat Endowment Fund, Chulalongkorn University. 
The selected writers not only criticise and compromise with censorship, but also thematise and translate it into their works.

Keywords: censorship; Modernism; Virginia Woolf; Allen Ginsberg; Czesław Miłosz; Bohumil Hrabal

\section{Introduction: The Unfinished Projects of Modernism and Censorship}

Censorship has often been regarded as an adversarial force which obstructs and (de)limits the work of artists, thinkers and writers. John Maxwell Coetzee (1940-) argues in Giving Offense: Essays on Censorship that censorship originates from and thrives in the dominant class's dread, paranoia and sense of powerlessness when faced with a writer/artist who articulates in his/her work views and opinions which "give offense". According to Coetzee's observation, the censorship regime is a name of the game which governs and pits writers/artists against politicians as they attempt to outsmart each other and rival in power play. The South African Nobel Prize-winning author wrote in his seminal work on censorship about the ways in which writers like him respond to censorship:

I cannot find it in myself to align myself with the censor, not only because of a skeptical attitude, in part temperamental, in part professional, toward the passions that issue in taking offense, but because of the historical reality I have lived through and the experience of what censorship becomes once it is instituted and institutionalized. Nothing in either my experience or my reading persuades me that state censorship is not inherently bad thing, the ills it embodies and the ills it fosters outweighing, in the long run and even in the medium run, whatever benefits may be claimed to flow from it (Coetzee, 1996, 9).

To a certain extent, the authors of this research paper share Coetzee's view on the unforgivable and unredeemable "ills" of institutionalised censorship. However, we would also like to contend that Coetzee's condemnation of censorship, however reasonable, is based on the clear-cut binary opposition of writer and censor, with the censor being the victimiser as opposed to the writer being the victim. This research paper proposes that censorship is not a total adversarial force which thwarts and hinders twentiethcentury writers, particularly those who were part of the artistic, aesthetic, 
philosophical and intellectual movement known as Modernism. Though Modernist writers openly condemn censorship, they nevertheless often work as censors who not only condone but also undergo self-censorship or censorship of others (particularly in the case where the writer in question was also a publisher like Virginia Woolf, as will be discussed). According to Robert Darnton, an author of Censors at Work, "to dismiss censorship as crude repression by ignorant bureaucrats is to get it wrong. Although it varied enormously, it usually was a complex process that required talent and training and that extended deep into the social order" (Darnton, 2015, 231). Censorship can also be seen as a significant drive which propels writers of the twentieth century to select, adapt, translate and appropriate the theme, motifs and methods of Modernist writings based on the revision, adaptation, translation and appropriation of the content, narratives, literary devices of classical texts such as mythology and legends in order to portray and convey the condition of being and living in the modern world - during the war and as an aftermath of war.

Censorship itself, as well as the reactions it instigates, is part of the Modernist project. Like Modernism, of which etymological root is modo, meaning "just now", censorship remains, to appropriate Jürgen Habermas's phrase, an "unfinished project". In Habermas's essay entitled Modernity: An Unfinished Project, delivered as a lecture in September 1980 upon receiving the Theodor W. Adorno prize from the city of Frankfurt, the "just now" moment, or the New, is described as constantly replacing the past with its fresh experimentalism while constantly being "displaced into the past". Modernism can therefore never reach its goal of remaining forever à la mode:

At this juncture, what was considered modern was what assisted the spontaneously self-renewing historical contemporaneity of the Zeitgeist to find its own objective expression. The characteristic feature of such works is the moment of novelty, the New, which will itself be surpassed and devalue in turn by the innovations of the next style. Yet whereas the merely modish becomes outmoded once it is displaced into the past, the modern still retains a secret connection to the classical. The 'classical' has always signified that which endures through the ages (Habermas, 1997, 39-40).

Similar to Modernism, which is paradoxically rooted in the classical and which can never attain and maintain the status of "newness", censorship is a system which can never fulfil its objective of absolute control. 
Censorship can only leave its trace when there are violations. One of the fine examples of the inevitable failure of censorship is the presence of underground publications in the Soviet Union. Robert Service, in The Penguin History of Modern Russia: From Tsarism to the Twenty-First Century, categorises such publications in his analysis of the rise of banned books in the Heyday of Nikita Krushchev as follows:

As Krushchev had become more illiberal, many intellectuals had taken to meeting in little groups and circulating typescripts of poems, novels and manifestos that were certain to be refused publication. This method of communication was known as samizdat (or self-publishing); and it was to acquire a broader technical range when tape-recorder cassettes became available. The latter method was known as magnitizdat (Service, 2015, 380).

The institutionalisation of censorship ironically bolsters the institutionalisation of samizdat, turning it into common practice. This venture opens up a space for intellectual growth, which initiates and fosters underground resistance. Also, particularly in the case of Modernist writers, censorship opens up spaces for readership and textual interpretation. It blurs the roles of the writer, the reader and the censor.

The Nobel laureate Alexander Solzhenitsyn (1918-2008), author of The First Circle and Cancer Ward who depicts "the lower levels of the political and social hierarchy under Stalin" (Service, 2015, 381), stresses the formidable role of literature in "accelerating history" in Soviet Russia (Darnton, 2015, 15). The power and significance of literature are nowhere most clearly augmented and put on centre stage than in the climate and terrain of censorship. The Modernist writers selected for analysis in this research paper, though alarmed by the marked limitations of sign system and disillusioned with the literary traditions of their predecessors in the postwar (after World War I) waste land of mass destruction and dehumanisation, still firmly upheld their belief in the transformative forces of language and literature as "accelerator of history", in Solzhenitsyn's sense, amidst political unrest and drastic changes. In this research paper, we shall see the ways in which Virginia Woolf (1882-1941), Allen Ginsberg (1926-1997), Czesław Miłosz (1911-2004) and Bohumil Hrabal (1914-1997) lived and wrote by negotiating with many forms of censorship ranging from state censorship, social censorship, political censorship, moral censorship 
to self-censorship. We shall see the ways in which they problematise and render ambiguity to the seemingly clear-cut and mutually exclusive division between the oppressive censor and the oppressed writer. These writers not only criticise and compromise with censorship, but also thematise and translate censorship into their literary works.

\section{Do We Know the Censor?: Virginia Woolf as the Censored Censor}

Though the word "censor" originally means a Roman official who, in the past, had a duty to "control access to writing" (Potter, 2013, 5), the agents of censorship - particularly those in the modern times - are not in every case overt and easy to identify. Taking into consideration Virginia Woolf's role as the censor and her position as the censored, readers of this research paper may find it hard to subscribe to a claim made by Sir William Joynson-Hicks (1865-1932), who was British Home Secretary from 1924-1929, in a pamphlet entitled Do We Need A Censor? that book censorship did not exist in Britain as there was no such official (Potter, 2013, 5). In Woolf's Orlando: A Biography (1928), the Roman censor is translated into a rigid and pedantic male biographer, an unofficial censored censor who cuts and edits, omitting the parts of his biographical subject's life whenever he is unable to cope with the "larger-than-life" turn of events-particularly those in the extraordinary five-century manly/womanly existence of Orlando, his biographical subject, thus censoring parts of his own work in the process. This reflects the ways in which the biographer is also censored by his society, along with its mainstream notions of morality and sexuality. Orlando's sex transformation from male to female rebels against the logic and tautology upheld by this biographer, who - like most biographers - prefers to define and pigeonhole individuals in absolutes and as flat characters. Woolf's playful and scathing creation and portrayal of the self-censoring biographer who fumbles and procrastinates whenever he encounters unaccountable and inexplicable episodes in Orlando's extraordinary life reflects her Modernist revolt against the norms and authority of the genres of biography, academic writing and historiographical writing. The authors of this research paper therefore subscribe to Celia Marshik's analysis in British Modernism 
and Censorship that "Woolf draws her reader's attention to the issue of censorship by dramatizing and satirizing the impulse to purify literature" (Marshik, 2006, 115).

Similar to the biographer in her novel, Woolf was also both censoring and censored in her role as a publisher. She was part of the system of censorship, particularly as she refused to publish James Joyce's Ulysses in 1918. However, it is important to note that Woolf's ban of Ulysses was reluctant. Though she wished to publish Ulysses, R. \& R. Clark and Clay, the printer approached by Leonard Woolf for this venture, nevertheless rejected their request for fear of legal prosecution (Marshik, 2006, 103). As Marshik explains, this fear was not at all unfounded. The printers and publishers in Woolf's time were subjected to the Obscene Publications Act 1857, also known as Lord Campbell's Act:

Under the 1857 Obscene Publications (Campbell) Act, publishers and printers were liable for financial penalties and losses should a work be convicted of obscene libel. Although obscenity prosecutions besmirched the reputation of the author of the work in the dock, the publisher and printer alone stood to lose financially under a guilty verdict (Marshik, 2006, 92).

Named after John Campbell (1779-1861), who served as a Chief Justice of Queen's Bench from 1850-1859, the Obscene Publications Act 1857 marked the beginning of modern English law and legal interpretation of obscenity. As Rachel Potter points out in Obscene Modernism: Literary Censorship \& Experiment 1900-1940, “the word 'obscene' is from the Latin obscēnus, meaning adverse, inauspicious, ill-omened; also abominable, disgusting, filthy, indecent. In this definition, the obscene person or thing needs to be cast out of the group to avoid contamination of other members" (Potter, 2013, 3). The 1857 legal translation of obscenity as a concept culminated in the Regina v. Hicklin case in 1868, where it was held that an obscene work of art or literature is that which corrupts the mind regardless of its artistic or literary merit. Potter further expounds on this notion in the context of twentieth century as follows:

The Obscene Publications Act of 1857, as well as the interpretation of this law in the Hicklin ruling of 1868, presided over the legal and editorial censorship of modernist writing. These pieces of legislation created both a particular structure of censorship, one which enfranchised individuals and pressure groups to do much of the work of cen- 
sorship, and a very loose definition of obscene writing. It was not necessary for a book to be considered obscene as a whole; it merely had to be shown that a small extract from a book, read out of context, had the 'tendency' to corrupt the mind of a young person (Potter, 2013, 2).

The agents who impose censorship, therefore, can never in many cases be directly named and truly known. In the case of Virginia and Leonard Woolf's stance in the publication of Joyce's masterpiece, printers and publishers become censors not because they embrace the duty of an official who is part of state or institutionalised censorship, but rather because they are, in turn, censored by the law and its economic consequences: "By refusing to take the risk of publishing it, they [Virginia and Leonard Woolf] put themselves in the position of having to enforce an externally imposed censorship that in all other respect they opposed" (Potter, 2013, 28).

The Obscene Publications Act 1857 was also instrumental in the 1928 trial of The Well of Loneliness, a novel by Radclyffe Hall (1880-1943). Published by Jonathan Cape in the same year as Virginia Woolf's Orlando, The Well of Loneliness was condemned and destroyed as the court deemed the depiction of lesbian love and relationship in the book obscene. It is also important to note that the book's persecution was triggered by an attack in the Sunday Express (Marshik, 2006, 140):

Cape decided to risk publication because of the potential sales value of the book and initially, it passed without notice, with some respectful if unenthusiastic reviews (it circulated for 6 weeks before Cape withdrew it). That all changed, however, when the infamous moral crusader James Douglas perused its contents. The next day his weekly Sunday Express column had the title A Book That Should Be Suppressed. Not only did the novel espouse a pseudoscientific sexological view of homosexuality that was specifically anti-Christian, but it also represented a toxic threat to the nation (Potter, 2013, 131).

In Hall's case, the reader-turned-critic therefore acted as agents who not only imposed censorship, but also promoted the censored book. The obscenity charges and the ensuing censorship paradoxically made Radclyffe Hall an instant bestselling author despite the fact that Virginia Woolf described Hall's banned work as a "meritorious dull book" (Woolf, 1982, 193), with its bluntly realist schema and romance narrative genre: "By 1929, it had become an international bestseller, with a number of translations appearing, most notably that of the highly respected French publisher, 
Gallimard. Cape went on to sell the American rights for $\$ 10,000$ with 20 per cent royalty" (Potter, 2013, 132).

The authors of this research paper would like to stress that, contradictory to the notion that Orlando was never in the radar of censorship which most readers of Woolf accept as true, Woolf's defiant spoof biography was mentioned in a letter from an unknown reader addressed to the Home Office: "The register records an anonymous letter regarding Orlando and summarizes the author's point thus: "Considers shd be suppressed»" (Marshik, 2006, 118). However, unlike in the case of The Well of Loneliness, no action was taken against Orlando. The irony is remarkable. While Hall's love story is realist and conventional in form and style, Woolf experiments with Realism as a literary schema by playfully adds in strange and magical elements in the life of Orlando, her protagonist, such as the tongue-in-cheek spoof preface, Orlando's arbitrary and inexplicable sex change, and Orlando's superhuman longevity which spans five centuries. Orlando: A Biography was never persecuted in the same way as The Well of Loneliness though Woolf's novel propels readers to question rigid chronological narration upheld by historians and biographers, as well as to unsettle the romance narrative, which tends to promote traditional and heteronormative ways of living and loving. While Orlando, Woolf's subject of her mock biography, is unapologetic, Stephen Gordon, Hall's lesbian protagonist, decides to give her lover, Mary Llewellyn, up to the expectations of heteronormative society which deprives them from the possibility of having "children, a home that the world would respect, ties of affection that the world would hold sacred, the blessed security and the peace of being released from the world's persecution" (Hall, 1968, 502). Gordon's dream of a traditional family enhances the apologetic and subdued tone in her final plea: "Give us also the right to our existence!" (Hall, 1968, 510), which is a stark contrast the bold and subversive message in Orlando. This is yet again a proof that readership and publishing industry can reinforce censorship. Likewise, censorship can enhance readership and publishing industry. 


\section{3. "And I am the King of May": Allen Ginsberg and the Symbolic Power of the Censored}

When Howl was published in Howl and Other Poems (1956) with the support of Lawrence Ferlinghetti (1919-) right after Allen Ginsberg had read it in front of a small audience in City Lights Bookstore, San Francisco, California, on 13 October 1955, not many people at that time knew that such was the beginning of a most significant censorship trial in the history of American literature. To avoid censorship, many books at that time were published outside the United States and shipped back to the country. Howl and Other Poems followed such itinerary and common practice. Unfortunately, in this particular case, the book failed to escape the awaiting trawl of censorship. The US customs agents confiscated 520 copies of Howl and Other Poems sent from London to San Francisco on the grounds of obscenity. Chester McPhee, Collector of Customs who was involved in seizing the copies, went as far as to comment that "the words and the sense of the writing is obscene. You wouldn't want your children to come across it" (Mellinkoff, 2006, 103). The censorship of Ginsberg's Howl and Other Poems was increasingly drastic to the extent that the booksellers at City Lights Bookstore were arrested by undercover police officers who played the roles of inquiring readers. Though the banning and persecution of Ginsberg's seminal poetry collection did not directly influence his published poems, this research paper proposes that the trial nevertheless caused lasting repercussions in the American literary scene. Because of the historic verdict ruled in favour of its publication and circulation, Howl and Other Poems was protected under the First Amendment of the United States Constitution, which "protects the right to freedom of religion and freedom of expression from government interference" (First Amendment, 2017). Apart from the direct consequence on Ginsberg's work, the Howl obscenity trial and verdict not only paved the way for freedom of expression among writers, but also encouraged readers to place importance on the value of freedom in the content of literature, particularly poetry, more than on literary convention and stylistic techniques. This leads to the growing confidence of artists and writers as well as to the advent of daring creative works, which are read and analysed for blatantly sexual and political messages. The long-term impact of the trial can be seen in the revolutionary 
attempt to revise the definition of "obscenity" pioneered by Judge Clayton W. Horn who addresses the following important question: Which particular part of literary work can be deemed "obscene" when each individual reader interprets and understands texts in his/her own different way? He comment:

The author of "Howl" has used those words because he believed that his portrayal required them as being in character. The People state that it is not necessary to use such words and that others would be more palatable to good taste. The answer is that life is not encased in one formula whereby everybody acts the same or conforms to a particular pattern. No two persons think alike; we were all made from the same mold but in different patterns. Would there be any freedom of press or speech if one must reduce his vocabulary to vapid innocuous euphemism? An author should be real in treating his subject and be allowed to express his thoughts and ideas in his own words... In considering material claimed to be obscene it is well to remember the motto: "Honi soit qui mal y pense" (Evil to him who evil thinks) (People V. Ferlinghetti, 1957).

The censorship of Howl and Other Poems not only bolstered the public's awareness of the power and subjectivity of textual interpretation, but also secured Allen Ginsberg's fame as one the greatest American writers to the extent that Lawrence Ferlinghetti scathingly expressed his wish to present a medal to the censoring customs agents who confiscated the 520 copies of Ginsberg book:

Because William Hogan, the San Francisco Chronicle's book review editor, turned over his Sunday column, "Between the Lines," to the booksellers, Ferlinghetti could respond publicly to the government's actions. In his printed statement, he made three basic points: 1) The publicity argument: "The San Francisco Collector of Customs deserves a word of thanks for seizing Howl and Other Poems and thereby rendering it famous. Perhaps we could have a medal made. It would have taken years for critics to accomplish what the good collector did in a day, merely by calling the book obscene." 2) The literary merits argument: "I consider 'Howl' to be the most significant single long poem to be published in this country since World War II, perhaps since Eliot's Four Quartets." 3) The dissent argument: If "Howl" is "a condemnation of our official culture, if it is an unseemly voice of dissent, perhaps this is really why officials object to it. In condemning it, however, they are condemning their own American world. For it is not the poet but what he observes which is revealed as obscene.... Considering the state of the world (not to mention the state of modern poetry) it was high time to howl" (Collins, Skover, 2013, 245-246).

The story of the Howl obscenity trial and its consequences did not end in the United States. Another example of the contribution of censorship 
to literary fame can be seen reflected in Ginsberg's visit to the Czechoslovak Socialist Republic on 18 February 1965 from Cuba (Blažek, 2012, $35)$. The conservative allegations against the obscene language and subject matter in Ginsberg's poetry could be found reiterated in the mainstream and state-sanctioned views of the poet (oft-times more so than his writing) in the Socialist Czechoslovakia. In Joyful Tanks Meet Gay Poet: Commemorating Liberation by 'America' in the Age of Global War on Terror, Kryštof Kozák explains:

On the surface, the images of the parade look similar to official marches encouraged by the communist regime. Closer inspection, however, reveals the playful, ironic and at times subversive aspects of the event, which is mostly evident on the signs that the marching students hold and in the hyperbolic tone of the moderators of the event (Kozák, 2016, 107).

Though, on the surface, Allen Ginsberg with his anti-capitalist and anti-establishment stance seemed a potential "poster boy" of the communist regime during the Cold War, the obscenity trial and the poet's support of homosexuality, as well as sexual freedom, were nevertheless destructive and deconstructive to the communist norms and morality, which place complete devotion to the party above all personal gains and pleasures. Ginsberg was reported to have "spent most of his time in Prague at Viola café, drinking alcohol and pursuing numerous sexual encounters with his young male Czech admirers" (Kozák, 2016, 107). His other behaviour and activities deemed subversive to the state were also remembered and later recounted: "Ludvík Hess recalled that on that occasion an unusual autograph session took place; one of his admirers asked him to sign The Communist Manifesto. Ginsberg crossed out the names of Marx and Engels and signed his own name as author" (Blažek, 2012, 37). The crowning of the Beatnik as Král Majáles [King of May] at the Student Festival, which marked the $20^{\text {th }}$ anniversary of the liberation of Czechoslovakia by the Soviet Army (Blažek, 2012, 39), has therefore been considered as a pivotal moment of Czechoslovak youth's counter-culture. Such landmark moment overtly challenged the communist regime's attempt to hijack the folk tradition of fertility rites to serve its propagandic agenda targeted on the nation's youth. Despite the disapproval expressed by the state, Ginsberg was chosen by the Czechoslovak youth as their King of May upon his first visit in 1965. The crowning of Ginsberg 
was the momentous act of dissidence which challenged the ideological purposes of the Student Festival held on the first of May. It was therefore not only a strong symbol of defiance, but also one of the transnational impacts of the censorship trial in the United States: "The American poet rode with the parade in a vintage car that the students had sent to the hotel to pick him up. Some students walked in front of the vehicle bearing a banner reading Ginsberg for King of May, an expression of proletariat internationalism" (Blažek, 2012, 42).

After being deported from Czechoslovakia on the grounds of corrupting the country's youth, Ginsberg wrote "Kral Majales", a poem which captures his impression of, experience in and expulsion from Czechoslovakia while sitting on the plane to London: "For I was arrested thrice in Prague, once for singing drunk on Narodni street,/once knocked down on the midnight pavement by a mustached agent who screamed out: BOUZERANT ["faggot", in Czech],/once for losing my notebooks of unusual sex politics dream opinions,..." (Ginsberg, 1998, 185). He would later return to the Czech and Slovak Federative Republic in 1990 and to the Czech Republic in 1993 after the dissolution of Czechoslovakia. His legacy as King of May and King of counter-culture, which led to the Velvet Revolution, has lived on. Jiří Zochr's Master's thesis entitled Allen Ginsberg, spontánní psaní, poezie. [Allen Ginsberg in Olomouc: Allen Ginsberg's Lecture on Spontaneous Writing with Commentary], which was submitted in 2014, offers a transcription of Ginsberg's lectures on the topic of "Writing Your Mind" (Zochr, 2014, 63) at Palacký University in Olomouc in 1993. In the lecture series held between 24 November and 2 December 1993, Ginsberg's attempt to encourage young people to engage in spontaneous writing, or writing without external and internal censorship, can be seen as a legacy of the "rebel" persona wrought by his ordeal and experience with censorship both in the United States and in the Czechoslovak Socialist Republic, respectively. In the first session, Ginsberg was recorded to say the following to a mixed audience of students and interested public:

I will be teaching this first class by means of slogans, just like Chairman Mao. Single one-line sentences or slogans.

We have a sort of modern mind in the $20^{\text {th }}$ century, somewhat fragmented, like in music video, where there's a series of discontinuous images. And so poetry has come, like television, to use modern forms, primarily montage, juxtaposition, images set by each 
other with no linear explanation, like music video. We're all familiar with music video? Is that visible here? (Zochr, 2014, 75).

Ginsberg playful reference to and appropriation of Mao Tse-tung and his anti-freedom-of-speech propaganda complements his description of the twentieth-century "modern mind", which delights in poetry with characteristics of a music video. Such anti-communist discourse and comparison lead to the question on censorship he sympathetically posits to the audience in Olomouc: Are music videos visible to you, whose perception of art and literature has previously been censored and limited by the socialist state?

To conclude this section's analysis, the authors of this research paper subscribe to Marshik's argument that censorship stimulates the writers to (re-)invent themselves as champions of the "new" and counter-culture:

Charges of indecency and obscenity both enabled and compelled artists to assert their modernity, to cast themselves as a vanguard. Such polemics also allowed writers to shape their public personae. By positioning themselves as anti-censorship, they appealed to like-minded readers and inscribed themselves in the social text as bold defenders of artistic freedom, a posture that concealed or obscured their many and varied acts of compliance with censorship and the moral standards of the purity movement (Marshik, 2006, 5).

Censorship has helped to establish Allen Ginsberg as the symbol of resistance and dissidence which transcends time, places, societies, cultures and political regimes.

\section{You'll be a Proper Writer: \\ Bohumil Hrabal and Self-Censorship in a Totalitarian State}

Censorship in service of the preservation and strengthening of communist ideology and power had a permanent presence in Czechoslovakia during the four decades of the communist regime, from 1948 to 1989. Yet, the censorship's management, administration, intensity and methods varied according to the context of the political situation in the country and, therefore, there were several basic phases of censorship in Czechoslovakia - from the Stalinist phase through a rise of liberalisation culminated in the 
Spring of 1968 to the 20-year period of the so-called Normalisation, from 1969 to $1989 .{ }^{1}$

Until the Prague Spring of 1968, censorship was institutionalised and executed by the organs of Communist Party of Czechoslovakia with a strong presence of the Ministry of Interior's secret agents ${ }^{2}$. The first signs of liberal trends, particularly among younger generation of writers, poets, theatre and cinema artists, began to appear from the mid-1960s and were significantly boosted after January 1968, when the iconic period of Prague Spring started. On 4 March 1968, the Central Publishing Administration was terminated. ${ }^{3}$ This was the first time that censorship was completely abolished in a communist country. Shortly after the Soviet occupation of Czechoslovakia on $21^{\text {st }}$ August 1968, National assembly adopted an "Act on some transition measures in the area of press and other mass information media". This act reinstalled censorship which was directed primarily at "pro-Soviet" journalistic coverage of the invasion. However, unlike before 1968, during the Normalisation period between the 1970s and the 1980s no institutionalised censorship took place and the responsibility for censoring the publications fell upon editors and editors-in-chiefs ${ }^{4}$. Selfcensorship, the pressure from being threatened and caught in a trap, as well as general distrust had devastating impact on peoples' psychical and physical health. The abolishment of censorship, the opening of space to free expression of thoughts and creativity and the rehabilitation of authors who had been for many years banned or marginalised were the first steps taken after the collapse of communism in Czechoslovakia.

Against this historical, political and ideological backdrop, Bohumil Hrabal lived, wrote, and struggled to have his works published and circulated. Oftentimes he could not publish and reach his readers. Even if

${ }^{1}$ The history of censorship in Czechoslovakia was first elaborated by Karel Kaplan and Dušan Tomášek (1994). Fundamental is a comprehensive two-volume monograph by Michael Wögerbauer, Petr Píša, Petr Šámal, Pavel Janáček et al. (2015).

${ }^{2}$ Records of the Central Committee of the Communist Party of Czechoslovakia are in the $4^{\text {th }}$ Department of the National Archives of the Czech Republic. This is currently one of the largest collection which is almost entirely catalogued.

${ }^{3}$ On legislative basis, censorship was abolished by the National Assembly in the end of June 1968.

${ }^{4} \mathrm{~A}$ comprehensive work on the Czech publishing policies and publishing houses under the communist regime can be found in: Přibán̆, 2015. 
this research paper addresses the later stages of Normalisation in Hrabal's lifetime, there is no doubt that Hrabal, who was 34 years old when the communists took power, was deeply influenced by the political and social climate in his country throughout his life.

Though Hrabal is considered to be one of the Czech authors about whom scholars have written most frequently, and though bibliography of academic studies, articles in serious non-academic magazines, as well as interviews with Hrabal and with people who were close to him amount to dozens of titles, the authors of this research paper acknowledge the fact that there are still many aspects of his life and work for readers to learn and to understand. ${ }^{5}$ The censor/censored dialectic is nowhere dramatically deconstructed as in Bohumil Hrabal's intimate portrayal of life under or, rather, in collaboration with totalitarian regime. In one of his unsent letters to April Gifford, an American student of Czech Studies, who has been given the loving nickname of "Dubenka" ["Duben" in Czech is derived from the word "dub" which literally means "oak". Hence "Duben" means "April", which is regarded as the "oak month"] (Hrabal, 2014, 25) dated 27 August 1989, Hrabal describes his attitude towards the communist informants thus: "I liked siting with all those police helpers, and why? Because as Patriarch Pimen made clear to me in Moscow, they are also children of God, Immanuels just like Kant" (Hrabal, 2014, 40). Hrabal not only admits that he finds no difficulty in being friendly with censoring informants, but also reveals in an interview with a journalist from Denmark that he willingly assumes his bestowed role of a "writing coach" for Vlasta, one of the secret police officers:

Vlasta swept aside the straw, lay down beside me, and took something out of his official bag... I half-closed my eyes, thinking he'd pull out a copy of Vacant Lots, but he only took out his notebook... we lay there and he confessed to me he'd like to write, was it difficult to become a writer?... I conducted this course five times in all, he drove up in the Volga and lay down beside me... I brought him Babel's Red Cavalry, but he gave it back saying he'd never manage it, so I gave him early Chekhov short stories, and he liked that... But finally I got an idea... Look, chief, write your stories the way you'd write a report... (Hrabal, 2014, 188-189).

From the excerpt, the fear of being arrested by the secret police for $\mathrm{Va}$ cant Lots, which was published as a samizdat, is not the only factor which

${ }^{5}$ V. Češka, 2015, 1271-1283. 
brings Hrabal closer to his censor. The binary opposition of victimiser and victim, as well as of censored and censor, is here challenged as the captor and the captive become friends who help each other read, write and create work of art. ${ }^{6}$

Living constantly in dread of being arrested and persecuted as he had no intention to leave country and begin his new life as an expatriate writer, Hrabal needed to overcome the fear that his freedom to write and to travel would be taken away from him. Hrabal's plight of having to cope with a subtler type of censorship, that which is coated with the best intension and friendly words, goes in line with the form of censorship described by Catherine O'Leary in Censorship Across Borders as follows:

There are other, less obvious forms of censorship also, including the humiliation, harassment and exclusion of authors, the imposition of fines, loss of employment, and public campaigns against certain writers, deemed enemies, not of the state, but of the people. The purpose of censorship is not only to prevent the dissemination of an unapproved message but also, in the longer term, to break the spirit and destroy the will or ability of the writer to defend himself (O’Leary, 2011, 6).

In exchange for exit permits to Salonika and Mount Athos in Greece for himself and for his wife, Hrabal chose to endure the authority's "false friendly slap on the back" (Hrabal, 2014, 164) after having answered a visa and passport officer's patronising question of whether or not he would like to have the freedom to travel abroad. The choice was simple. It was either to have his freedom to leave the country for a vacation taken away or to be granted such freedom on the condition of his denouncing his friend of Ludvík Vaculík (1926-2015), the author of the "Two Thousand Words" manifesto of June 1968 who had been under the authority's censoring radar:

\footnotetext{
${ }^{6}$ For this reason, Hrabal had to face strong criticism from some dissidents and underground authors. Češka, 2015, 1276-1277, records that Ivan Magor Jirous organised the burning of Hrabal's books, referred to as an autodafé, which was attended by thirteen people. This took place in 1975, right after Jirous had read Hrabal's interview for communist weekly Tvorba: "Hrabal spoke about soccer, but also said in passing that in the coming elections he would vote for candidates of the National Front, as the forced coalition of all parties was euphemistically called. This sop was sufficient; his loyalty declaration could be manipulated, but he did not protest, and his books reappeared in bookshops" (Bažant, 2010, 397).

V. also: Nezbeda, 2014.
} 
Vaculík, or Salonika?... Salonika, I said... He laughed and handed me my passport, with the tip of an exit permit poking out... And then he said, with infinite bonhomie... Just as I thought... I mean, you're a writer, know what I mean, but who is that Vaculík fellow? Sure, he gets money from abroad... but what's he compared with someone like you... you are and will be a writer... I'm a doctor of philosophy, I promise you, you'll be published again, you'll be a proper author, not like him... the crook! (Hrabal, 2014, 164)

For Hrabal, there was no greater fear than a writer's fear of not being able to publish and disseminate his/her work. Such fear overpowered his wish to participate in the dissident movement which led to the Velvet Revolution, particularly the signing of petitions, particularly "A Few Sentences" ["Několik vět"], a petition published on 29 June 1989 which "contained 7 recommendations. These were not categorically formulated requests: The release of political prisoners, freedom of assembly, the legalisation of independent initiatives, freedom of the press and public expression, recognition of the rights of churchgoing citizens, the immediate resolution of the catastrophic ecological situation and free discussions on the history of Czechoslovakia after 1948" (Suk, 2009):

I was even honoured by a visit to the Golden Tiger by kind Václav Havel, who'd written me a note, saying he wanted to come and see me, but I'd left, because I was having dinner at six with a friend, and Václav only got to the Tiger after seven - and my friends became enemies, when they looked for me in the Tiger, they even shouted... Where's that collaborator? And I preferred to be this collaborator, because, Dubenka, as I also said to Václav Havel that Saturday afternoon when with a thousand other people I celebrated the anniversary of the French Revolution in the gardens of the French Embassy, I said to him... Yes, Václav, maybe that day in the Tiger I would have signed it, but not any more. And why? Because I wouldn't swap 'A Few Sentences'for the eighty thousand afterwords by Milan Jankovič... I mean, Dubenka, the only purpose of my being in this world has been to write this Too Loud a Solitude, that Solitude which Susan Sontag in New York said was one of the books, the twenty books that would form the image of the writing of this century... (Hrabal, 2014, 73-74)

Here, Hrabal renders "A Few Sentences" incomparable to Too Loud a Solitude, his novella which depicts the comically tragic and tragically comical story of a bibliophile who needs to subject himself to the regime and be part of the censorship enterprise by destroying books and knowledge, what he loves most in life, for his living. From the extract, Hrabal gladly pays the price for the publication of his masterpiece, which includes the afterword by the philosopher Milan Jankovič, in the currency of silence and submission. 
Like Haňt’a, the (self-)censoring and paper-pulping protagonist of this novella which was not officially published until 1989 due to censorship, Hrabal is resigned to the fact that he cannot topple the political regime of his country, or what he calls the "status quo". However, as a writer, he does not believe that there is only one form of political dissidence: Havel's modus operandi as reflected in Charter 77 or the subsequent "A Few Sentences", which was described by James Krapfl in Revolution with a Human Face as "the first citizens' petition critical of the Communist regime to break the divide between dissident groups and the rest of the population" (Krapfl, 2013, 206). As a writer, Hrabal only wishes to write and to have his writing published in the midst of the conflicting political creed and ideology. Writing, for him, can never be his modus operandi - habits of working - as he is resigned to the fact that he is living in a disputed space, a "literary laboratory", which is Central Europe.Writing is, rather, Hrabal's modus vivendi - ways of living practically under censorship and totalitarianism

You see, I recognize the status quo: that the political situation can't be altered, everything that has been done cannot be undone, which means I live in a land of limited sovereignty, as they said to us in that unhappy year of nineteen sixty-eight, after the twenty-first of August - a time which is now rising again from the dead, but I am shocked and scared and horrified at this, I don't want anything to happen here, to give the armed angels from the tiled nick a cause to intervene... I was always a man of the status quo, but at the same time I'm a man who wishes to have his modus vivendi, to be able to say what is the essence of literature, to express my own glasnost, my own opinions, not that I would pay for it and pay anything for it, but, as Hašek taught me, being a man of the Party of Moderate Progress, that is my modus vivendi in this Central Europe of mine, this literary laboratory from the first four decades of this century... (Hrabal, 2014, 40-41).

Bohumil Hrabal's encounter with and attitude towards censorship influence his writing, which is based on the conversation heard in local pubs, his favourite place: "Hrabal terms this chatty, free-association style, which is meant to evoke the cadences of a seasoned pub story teller, "pábitelstvi', his own neologism” (Kuhlman, 2008, 162-163). The term "pábitelstvi", equivalent to "palavering" in English, becomes the technique through which Hrabal expresses his political opinions under his apolitical guise. Radko Pytlik, in The Sad King of Czech Literature Bohumil Hrabal: His Life and Work, further elaborates this method's underlying subversive statement as follows: 
With their lively vitality, the "palaverers" undermine literary conventions. They attempt the forbidden. They reject the habit of perceiving the world with the help of symbols and ciphers, ideology, hackneyed phrases and pathos. The world of 'well-groomed' positive and politically conscious heroes is foreign to them (Pytlik, 2000, 51).

\section{Sharpened Consciousness: Czesław Miłosz and the Effects of Censorship}

In the first few years after the end of World War II, significant works reflecting pre-War Poland and the painful outcome of the war have been published. One of the most famous from those works was Jerzy Andrzejewski's novel Ashes and Diamonds (1948), later adapted into film by Andrzej Wajda. Andrzejewski cooperated in those years with Czesław Miłosz who later, in his exile, portrayed Andrzejewski in one of his novels.

The installation of the brutal and uncompromising Stalinist regime of the chairman of the Party and of the State, Bolesław Bierut, a hard-line Stalinist at that time, launched a gravely oppressive campaign in the end of 1940s and ended the promising post-war creative development. The communisation of the Polish culture became one of the official and enforced tactics and strategies of the regime. Many Polish writers and artists saw life in exile as their only escape. Censorship was administered by the Main (Head) Office for Control of Press, Publications and Performances (GUKPPiW). The 10-year Solidarity Movement against the Communist Regime in Poland contributed to the weakening of censorship in the 1980s. This phenomenon was not the case in Czechoslovakia. Censorship in Poland was abolished in 1990. Also, unlike Czechoslovakia, censorship in Poland was for almost fifty years supervised and managed by the same institution.

Czesław Miłosz, a Polish author and diplomat, chose in 1951 to live in exile to escape the most brutal manifestations of the communist regime in Poland (Woźniak-Łabieniec, 2009). For Miłosz, intellectuals - especially those in Poland under the regime between the years 1944-1989 - willingly embraced censorship as "involuntary subjective control" (Darnton, 2015, 241). Robert Darnton explains that such term connotes "an internalized assimilation of Communist doctrine inflicted not by force but by a need to find significance in the wake of World War II and the conquest of their country by its old enemy, Russia, with a new weapon, Stalinist dialectics" 
(Darnton, 2015, 241). Self-censorship, therefore, sustains the belief that only Socialism, especially Socialist Realism which ruled and regulated the realm of arts and literature, can render meaning to their lives in their post-war world:

\begin{abstract}
"Socialist realism" is much more than a matter of taste, of preference for one style of painting or music rather than another. It is concerned with the beliefs which lie at the foundation of human existence. In the field of literature it forbids what has in every age been the writer's essential task - to look at the world from his own independent viewpoint, to tell the truth as he sees it, and so to keep watch and ward in the interest of society as a whole (Miłosz, 1990, xii).
\end{abstract}

Such impact of censorship not only obliterates a citizen's sense of freedom and rights, but also corrupts the artists and writers' significant role upheld by Miłosz as most sacred, which is, their role to tell the truth regardless the price and punishment. Miłosz also recounted the following:

In 1949 the Party imposed the doctrine of socialist realism, making it obligatory for all writers. In terms of the novel form, socialist realism was both an attempt to go back to the nineteenth century and an enforcement of a goal prescribed from above. The themes allowed in 1945-1949 were either looked at askance or forbidden. The only models that were approved by the Party were the Soviet novels of the late 1930's and 1940's. Published in large editions, Polish socialist realist novels at first provided the officials with confidence as to the influence of literature upon the masses. In fact, they were bought under compulsion by a network of libraries, where they gathered dust on the shelves and were known as "bricks" (Miłosz, 1968, 114).

Socialist Realism, for Miłosz, may be equated to political totalitarianism in the world of art. However, with its ineffective measures - which only propelled the creation of dull "brick-like" books which no one really read for pleasure - Socialist Realism does not have the power and authority to hinder the artists and writers' creativity and deprive them of their freedom. Rather, it is the artists and writers' submission to censorship which leads to their failure to perform what Miłosz upholds to be their quintessential role and duty: to express and offer, without fear, their truthful interpretation of the world.

Considering Miłosz's choice to live in exile in order to preserve his freedom of thought and expression, this research paper nevertheless argues that censorship also does the opposite of what is often understood. One of the impacts of censorship, however unpleasant and coercive, is that writers 
like Miłosz choose to migrate to other countries and, by moving away from the regime, become exposed to other cultures and world order which in turn propel them to become much more disillusioned with their oppressive political system, as well as the suffocating norms. "Exile accepted as a destiny, in the way we accept an incurable illness," wrote Miłosz in his "Notes on Exile", "should help us see through our self-delusions" (Miłosz, 2002, 13). If exile is a fatal sickness for writers living in the waste land of narrow-mindedness, censorship can be regarded as both the cause which triggers the disease and the vaccine which helps to stimulate one's immune system, augmenting their critical view of their world, as well as their writing:

During the thirty years I have spent abroad, I have felt I was more privileged than my Western colleagues, whether writers or teachers of literature, for events both recent and long past took in my mind a sharply delineated, precise form. Western audiences confronted with poems or novels written in Poland, Czechoslovakia, or Hungary, or with films produced there, possibly intuit a similarly sharpened consciousness, in a constant struggle against limitations imposed by censorship (Miłosz, 1981, 20-21).

\section{Conclusion}

This research paper's textual and contextual analysis questions and challenges the widely-accepted claim that censors are dull officials who are naturally ignorant in that they lack the intellect to understand the subtlety and hidden message of the text in question:

Censorship is more complex and nuanced than a simple battle between the forces of oppression and the representatives of freedom of expression or the upholders of individual rights. It is a constant balancing act, even in democratic societies, that takes into consideration the avoidance of harm and the protection of both individual and collective rights. Yet one of the problems with debates about censorship is that they tend not only to focus on the moral and the political concerns of states or citizens, on individual and collective rights, on definitions of innocence and corruption, but are also coloured by emotion, the struggle for power, and blind faith (O'Leary, 2011, 5).

In the case of Modernist literature, writers act as censors to themselves and other writers. Virginia Woolf, the author of Orlando, an audacious spoof biography which ridicules censorship, was paradoxically censoring in her 
role as a publisher because she was, in turn, censored by the law and its economic threat. Allen Ginsberg's experience of censorship has led to the establishment of the writer himself as symbol of resistance and dissidence, of which power and significant are both transnational and transtemporal. Through reading and interpreting Bohumil Hrabal's works in light of the political context of his time, one can perceive how Hrabal sought to live and work practically as a writer under the totalitarian regime which closely monitored its writers. For a writer who has made a conscious choice of staying and working in his home country, Hrabal preferred his writing to be published, rather than to perish in oblivion. For a writer who has made a conscious choice of leaving his home country and working abroad, Czesław Miłosz turned his crisis into a once-in-a-life-time opportunity to gain exposure to other cultures, outlooks and political regimes. He then made the most out of censorship and exile by creating literary pieces which invite readers to think beyond the artistic and intellectual limitations conditioned by the authority, as well as to imagine an alternative world order beyond their own.

Modernist writers often function - whether knowingly or unknowingly - as part of the censorship mechanism: "Censorship and social purity were «necessary evils» that shaped modernist form and content even as writers resisted these forces" (Marshik, 2006, 206). Translating censorship encountered in their lives into their writing, the writers analysed in this research paper not only conform to and/or adapt to the censoring demands of their time, but also transcend the binary opposition censor as victimiser vs writers as victims.

\section{References}

Bažant, J. et at. (eds.) (2010). The Czech Reader: History, Culture, Politics. Durham-London: Duke University Press.

Blažek, P. (2012). The Deportation of the King of May: Allen Ginsberg and the State Security. In: BIC: Behind the Iron Curtain: Review of the Institute for the Study of Totalitarian Regimes. Prague: Institute for the Study of Totalitarian Regimes, pp. $35-47$.

Coetzee, J.M. (1996). Giving Offense: Essays on Censorship. Chicago: University of Chicago Press.

Collins, R., Skover D.M. (2013). Mania: The Story of the Outraged and Outrageous Lives That Launched a Cultural Revolution. Illinois: Top Five Books. 
Češka, J. (2015). Literatura z dosahu politické četby. Za Hrabalovou variantností a ironií. In: M. Wögerbauer, P. Píša, P. Šámal, P. Janáček et al. V obecném zájmu. Censura a sociální regulace literatury v modern české kultuřre 1749-2014. Prague: Academia, pp. 1271-1283.

Darnton, R. (2015). Censors at Work: How States Shaped Literature. New York: W.W. Norton.

First Amendment (2017). Legal Information Institute. Cornell Law School. https:// www.law.cornell.edu/wex/first_amendment. 03.03.2018.

Ginsberg, A. (1998). Kral Majales. "Massachusetts Review", vol. 39, issue 2. (Summer). pp. $185-186$.

Habermas, J. (1997). Modernity: An Unfinished Project. Eds M. Passerin d'Entrèves, S. Benhabib. Habermas and the Unfinished Project of Modernity: Critical Essays on The Philosophical Discourse of Modernity. Cambridge, Massachusetts: MIT Press, pp. 38-55.

Hall, R. (1968). The Well of Loneliness. London: Corgi.

Hrabal, B. (2014). Total Fears: Letters to Dubenka. Trans. J. Naughton. Prague: Twisted Spoon Press.

Kaplan, K., Tomášek, D. (1994). O cenzuře v Československu v letech 1945-1956. Prague: Institute for Contemporary History of Academy of Science.

Kozák, K. (2016). Joyful Tanks Meet Gay Poet: Commemorating Liberation by 'Ameri$\mathrm{ca}^{\prime}$ ' in the Age of the Global War on Terror. "RIAS: Review of International American Studies", vol. 9 (Fall-Winter), No. 2, pp. 87-118.

Krapfl, J. (2013). Revolution with a Human Face: Politics, Culture and Community in Czechoslovakia 1989-1992. New York: Cornell University Press.

Kuhlman, M. (2008). The Silence of the Page Une trop bruyante solitude: The Graphic Novel Adaptation of Too Loud a Solitude by Bohumil Hrabal. "European Comic Art" Vol. 1, No. 2, pp. 157-171.

Marshik, C. (2006). British Modernism and Censorship. New York: Cambridge University Press.

Mellinkoff, A. (2006). Morning Report: Iron Curtain on the Embarcadero. "San Francisco Chronicle" (28 March 1957). Howl on Trial: The Battle for Free Expression. Eds. B. Morgan, N.J. Peters. San Francisco: City Lights Books.

Miłosz, C. (1968). The Novel in Poland. In: Ed. with Intro. H. Peyre. Fiction in Several Languages. Boston: Houghton Mifflin, pp. 105-121.

Miłosz, C. (1981). Nobel Lecture. New York: Farrar Straus Giroux.

Miłosz, C. (1990). The Captive Mind. Trans. J. Zielonko. Vintage International Edition. New York: Vintage.

Miłosz, C. (2002). "Notes on Exile". To Begin Where I Am: Selected Essays. Ed. with Intro. B. Carpenter, M.G. Levine. New York: Farrar, Straus and Giroux, pp. $13-19$.

Nezbeda, O. (2014). Bohumil Hrabal v osidlech censury. Jak komunisté ovládli nejlepšího českého spisovatele. "Respekt", No. 13. https://www.respekt.cz/tydenik/2014/13/normalizacni-partie-lbohumila-hrabala. 03.03.2018. 
O'Leary, C. (2011). Introduction. In: Censorship Across Borders: The Reception of English Literature in Twentieth-Century Europe. Eds C. O’Leary, A. Lázaro. New Castle upon Tyne: Cambridge Scholars Publishing, pp. 1-24.

People V. Ferlinghetti. (1957). San Francisco Municipal Court. 3 October 1957.

Potter, R. (2013). Obscene Modernism: Literary Censorship \& Experiment 1900-1940. Oxford: Oxford University Press.

Přibáň, M. et al. (2015). Česká literární nakladatelství 1949-1989. Prague: Academia.

Pytlik, R. (2000). The Sad King of Czech Literature Bohumil Hrabal: His Life and Work. Prague: Emporius.

Service, R. (2015). The Penguin History of Modern Russia: From Tsarism to the Twenty-First Century. $4^{\text {th }}$ Ed. London: Penguin.

Suk, J. (2009). 'A Few Sentences' on a Petition From 1989. 19.06.2009. https://icv.vlada.cz/en/media-centrum/tema/a-few-sentences-on-a-petition-from-1989-59398/ tmplid-676/. 03.03.2018.

Wögerbauer, M., Píša, P., Šámal, P., Janáček, P. et al. (2015). V obecném zájmu. Censura a sociální regulace literatury v modern české kultuře 1749-2014. Prague: Academia.

Woolf, V. (1982). The Diary of Virginia Woolf: Volume 3, 1925-30. Ed. A.O. Bell. Assist. A. McNeillie. Harmondsworth: Penguin.

Woźniak-Łabieniec, M. (2009). Strategie literackie wobec zapisu cenzury. Czesław Miłosz w krajowej prasie i poezji w latach pięćdziesiatych. „Napis”, No. XV. http://rcin.org.pl/Content/54127/WA248_65860_P_I_2795labienec_strategie.pdf. 03.03.2018, pp. 311-326.

Woźniak-Łabieniec, M. (2012). Obecny nieobecny. Krajowa recepcja Czesława Miłosza w krytyce literackiej lat pięćdziesiatych w świetle dokumentów cenzury. Łódź: Wydawnictwo Uniwersytetu Łódzkiego.

Zochr, J. (2014). Allen Ginsberg, spontánni psani, poezie. [Allen Ginsberg in Olomouc: Allen Ginsberg's Lecture on Spontaneous Writing with Commentary]. Master's Thesis (Philology/English Philology). Philosophical Faculty, Palacký University in Olomouc. 